Keywords: $M C U, A R P, I S D P$

Retention: Permanent

\title{
RESULTS FROM ANALYSIS OF THE FIRST AND SECOND STRIP EFFLUENT COALESCER ELEMENTS FROM RADIOACTIVE OPERATIONS OF THE MODULAR CAUSTIC- SIDE SOLVENT EXTRACTION UNIT
}

\author{
T. B. Peters \\ F. F. Fondeur \\ S. D. Fink
}

June, 2011

Savannah River National Laboratory

Savannah River Nuclear Solutions

Aiken, SC 29808

Prepared for the U.S. Department of Energy under

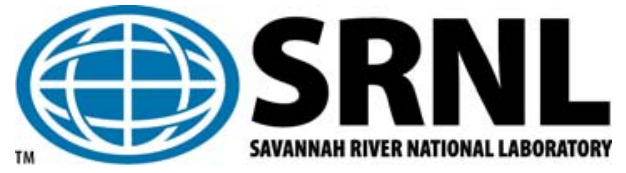
contract number DE-AC09-08SR22470. 
SRNL-STI-2010-00088

Revision 0

\section{DISCLAIMER}

This work was prepared under an agreement with and funded by the U.S. Government. Neither the U.S. Government or its employees, nor any of its contractors, subcontractors or their employees, makes any express or implied:

1. warranty or assumes any legal liability for the accuracy, completeness, or for the use or results of such use of any information, product, or process disclosed; or

2. representation that such use or results of such use would not infringe privately owned rights; or

3. endorsement or recommendation of any specifically identified commercial product, process, or service.

Any views and opinions of authors expressed in this work do not necessarily state or reflect those of the United States Government, or its contractors, or subcontractors.

Printed in the United States of America

Prepared for

U.S. Department of Energy 


\section{REVIEWS AND APPROVALS}

\section{AUTHORS:}

T. B. Peters, Author, SRNL/SASP

Date

F. F. Fondeur, Co-Author, SRNL/SASP

Date

TECHNICAL REVIEW:

C. A. Nash, Technical Reviewer, SRNL/AC\&P

Date

APPROVAL:

S. D. Fink, SRNL/SASP, Manager

Date

S. L. Marra, SRNL/E\&CPT Research Programs, Manager

Date

D. J. Martin H Tank Farm Engineering

Date 


\section{EXECUTIVE SUMMARY}

The coalescer elements for the Strip Effluent (SE) acid within the Modular Caustic-Side Solvent Extraction Unit (MCU) experienced elevated differential pressure drop during radioactive operations. Following the end of operations for the first Macrobatch campaign and soon after start of the second Macrobatch campaign, personnel removed the coalescer media and provided to Savannah River National Laboratory (SRNL) for diagnostic investigation of the causes of reduced flow. This report summarizes those studies.

Two Strip Effluent (SE) coalescers were delivered to the Savannah River National Laboratory (SRNL). One was removed from the Modular Caustic-Side Solvent Extraction Unit (MCU) between processing of Macrobatch 1 and 2 (coalescer "Alpha"), and the second was removed from MCU after processing of $\sim 24,000$ gallons of salt solution (coalescer "Beta"). Both coalescers underwent the same general strip acid flush program to reduce the dose and were delivered to SRNL for analysis of potential occluding solids.

Analysis of Coalescer Alpha indicates the presence of aluminum hydroxide solids and aluminosilicate solids, while analysis of Coalescer Beta indicates the presence of aluminum hydroxide solids, but no aluminosilicates.

Leaching studies on sections of both coalescers were performed. The results indicate that the coalescers had different amounts of solids present on them at the time of removal.

Finally, samples of free liquids retrieved from both coalescers indicate no excessive amounts of CSSX solvent present.

Given the strip acid flushing that occurred in the SE coalescers, the solids we detected on the coalescers are probably indicative of a larger quantity of these solids present before the strip acid flushing. Under this scenario, the excessive pressure drops are due to the solids and not from organic fouling. 


\title{
LIST OF ABBREVIATIONS
}

\author{
AD - Analytical Development \\ ARP - Actinide Removal Process \\ CSSX - Caustic-Side Solvent Extraction \\ DSSHT - Decontaminated Salt Solution Hold Tank \\ FTIR - Fourier Transform infra-red spectroscopy \\ ICP-ES - inductively-coupled plasma - emission spectroscopy \\ ICP-MS - inductively-coupled plasma - mass spectroscopy \\ ISDP - Integrated Salt Disposition Project \\ MCU - Modular CSSX Unit \\ MST - monosodium titanate \\ PuTTA - plutonium thenoyl trifluoroacetone scintillation \\ SEHT - Strip Effluent Hold Tank \\ SRNL - Savannah River National Laboratory
}




\subsection{Introduction}

The MCU uses two different coalescers to recover organic solvent from the exiting aqueous phases. One coalescer is used on the Decontaminated Salt Solution (DSS), and the other is used on the SE stream. Both are made of Ryton ${ }^{\circledR}$ (polyphenylene sulfide). The DSS coalescer has a nominal 20 micron particle removal rating - which means that if used as a filter, the unit will reject $99.98 \%$ of all particles 20 microns or larger - while the SE coalescer has a nominal 10 micron particle removal rating. During operations with Macrobatches 1 and 2, both types of coalescers at times have exhibited pressure drops in excess of the $<10$ psid expected from non-radiological testing (see Figures 1 and 2).

Figure 1. Differential pressure for Strip Effluent coalescer used during Macrobatch 1 (aka Coalescer Alpha).

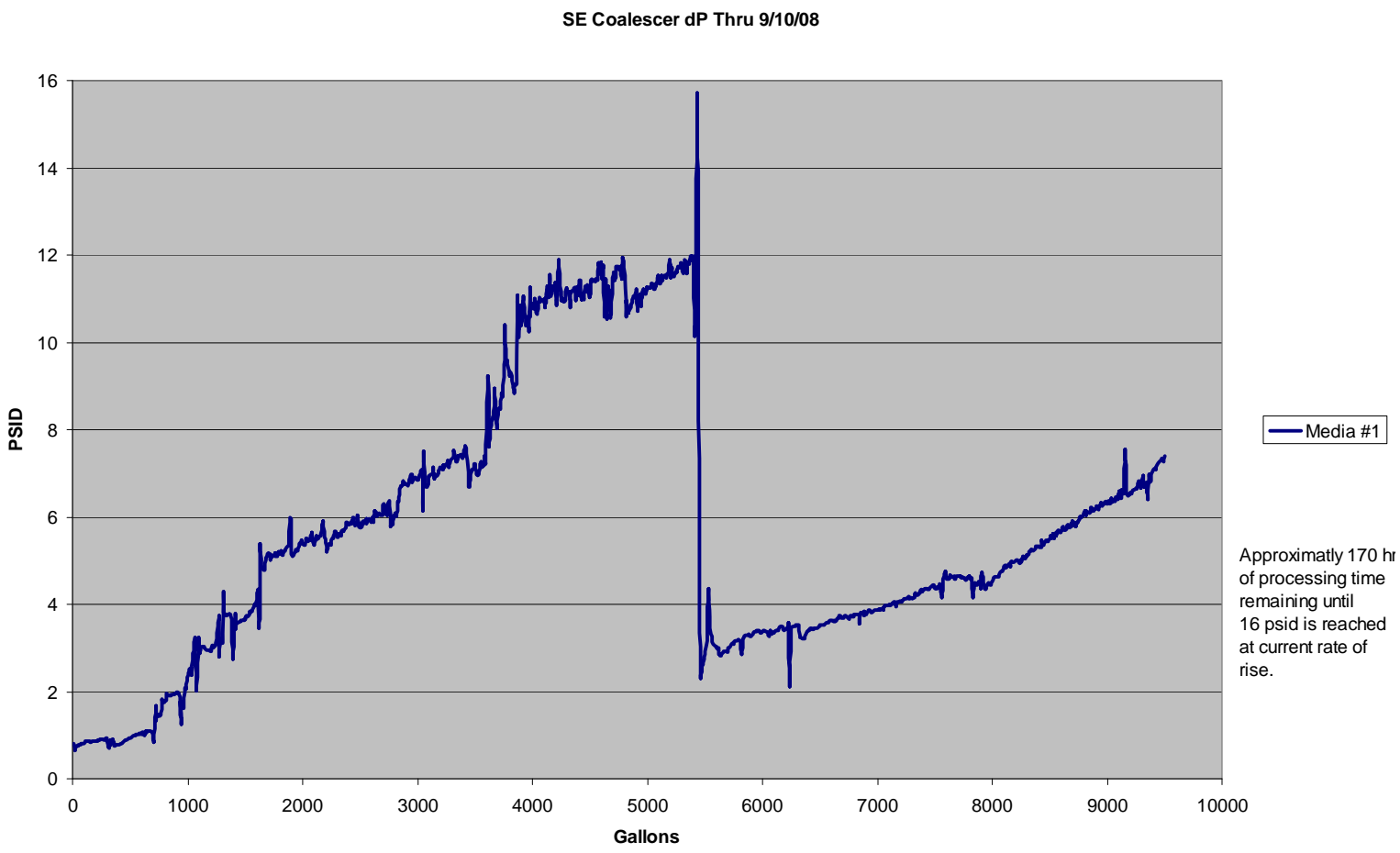

The DSS coalescer elements have been removed and analyzed on several occasions as the pressure drop became too high for continued operations. ${ }^{1}$ However, the pressure drop across the SE coalescers remained sufficiently low $(<20$ psid) during the initial radioactive operations to avoid an interruption of operations. ${ }^{\Upsilon}$ During non-radioactive testing of the

\footnotetext{
${ }^{\Upsilon}$ During non-radioactive operations, the SE coalescer plugged. See Appendix I.
} 
Figure 2. Differential pressure for Strip Effluent coalescer used during Macrobatch 2 (aka Coalescer Beta).

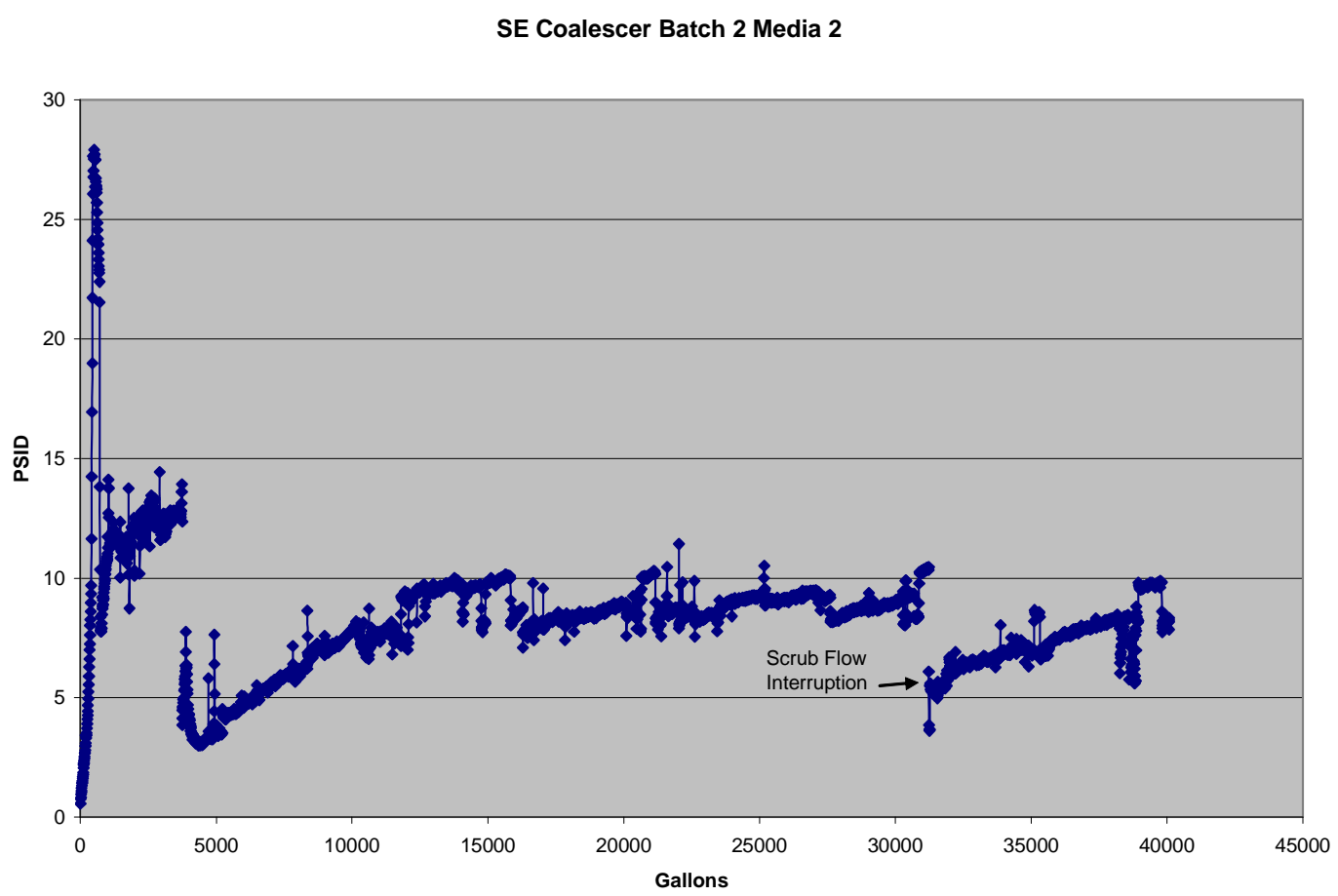

facility, a single fouling incident occurred for the SE coalescer. Appendix I discusses that event. The cause of that fouling involved fabrication debris - i.e., stainless steel fines - and an abnormal operating condition that led to emulsification of the solvent. Those causes are not germane to this current study but the data is presented for completeness and historical preservation.) At the end of the campaign for Macrobatch 1 (i.e., October 2008), the coalescer element (i.e., Coalescer Alpha) was removed from the facility and sent to SRNL for analyses.

During the processing of Macrobatch 2, the SE coalescer (Coalescer Beta) showed excessive pressure drop early in processing. On March 6, 2009, personnel doubled the scrub acid flowrate - as a means of reducing the likelihood of solids precipitation, which alleviated the pressure drop for some time. An expert panel review suggested this initial pressure drop after start of use for a new coalescer element may reflect organic fouling due to the pre-soak of the element in Isopar L ${ }^{\mathrm{TM}}$ prior to use. ${ }^{2}$

However, the pressure drop started increasing again. The facility underwent an outage of operations in late March 2009, and MCU personnel sent the SE coalescer to SRNL for analysis. 
SRNL-STI-2010-00088

\subsection{Experimental Procedure}

Samples of the coalescer were cut from the whole coalescer. These samples were removed and sub-sampled as necessary.

\subsection{Results and Discussion}

3.1 XRD Analysis When the coalescers arrived, the first analysis done on each was an X-ray diffraction (XRD) analysis of a sample cut from the coalescer. This method identifies types of crystalline or semi-crystalline solids in the sample. In both cases, a sample of the inner layer of the coalescers was removed from the stainless steel inner support, and sent for analysis with no other sample preparation. One sample was analyzed from Coalescer Alpha (see Figure 3), and two samples were analyzed from Coalescer Beta (see Figures 4 and 5).

Figure 3. XRD Spectra for Coalescer Alpha

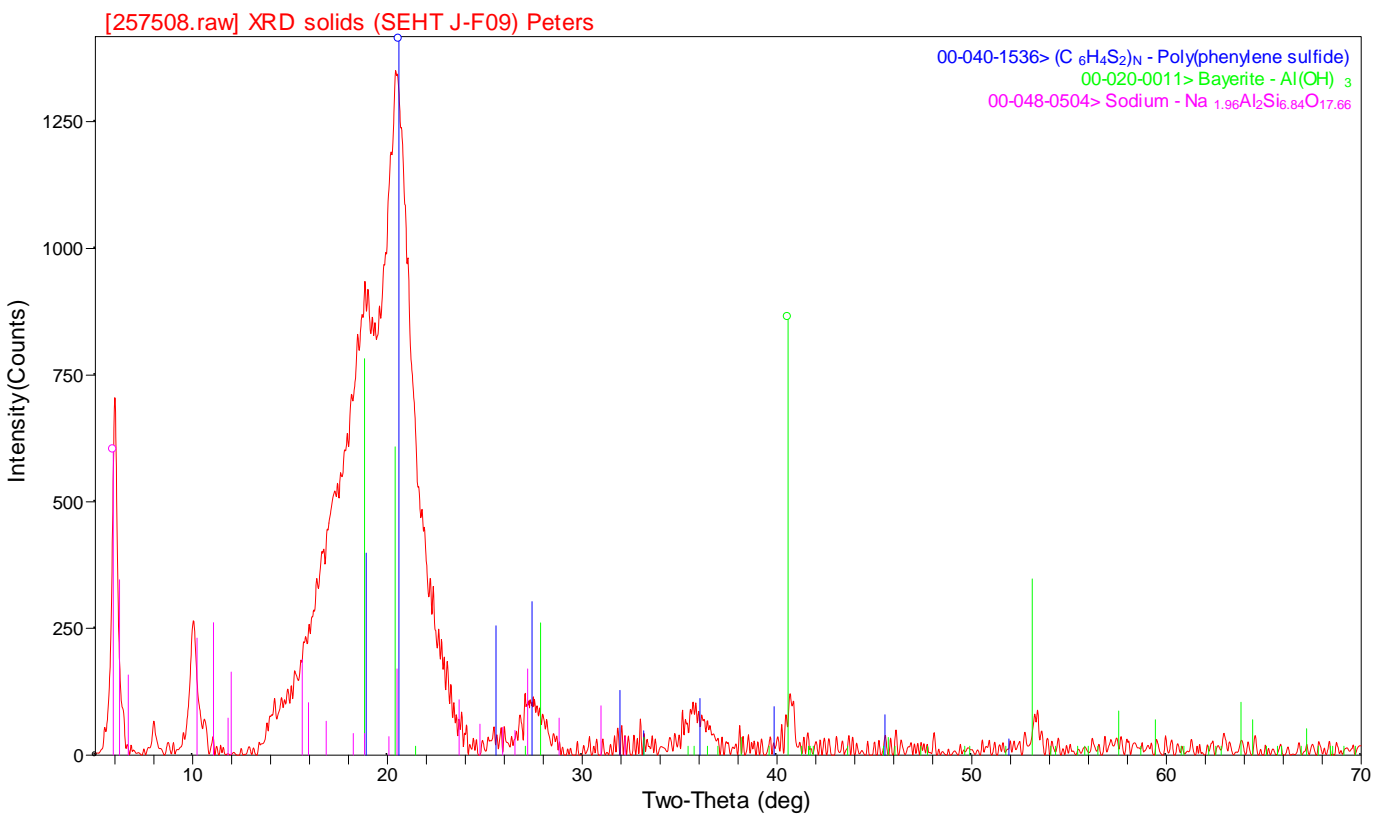


SRNL-STI-2010-00088

Figure 4. XRD Spectra \# 1 for Coalescer Beta

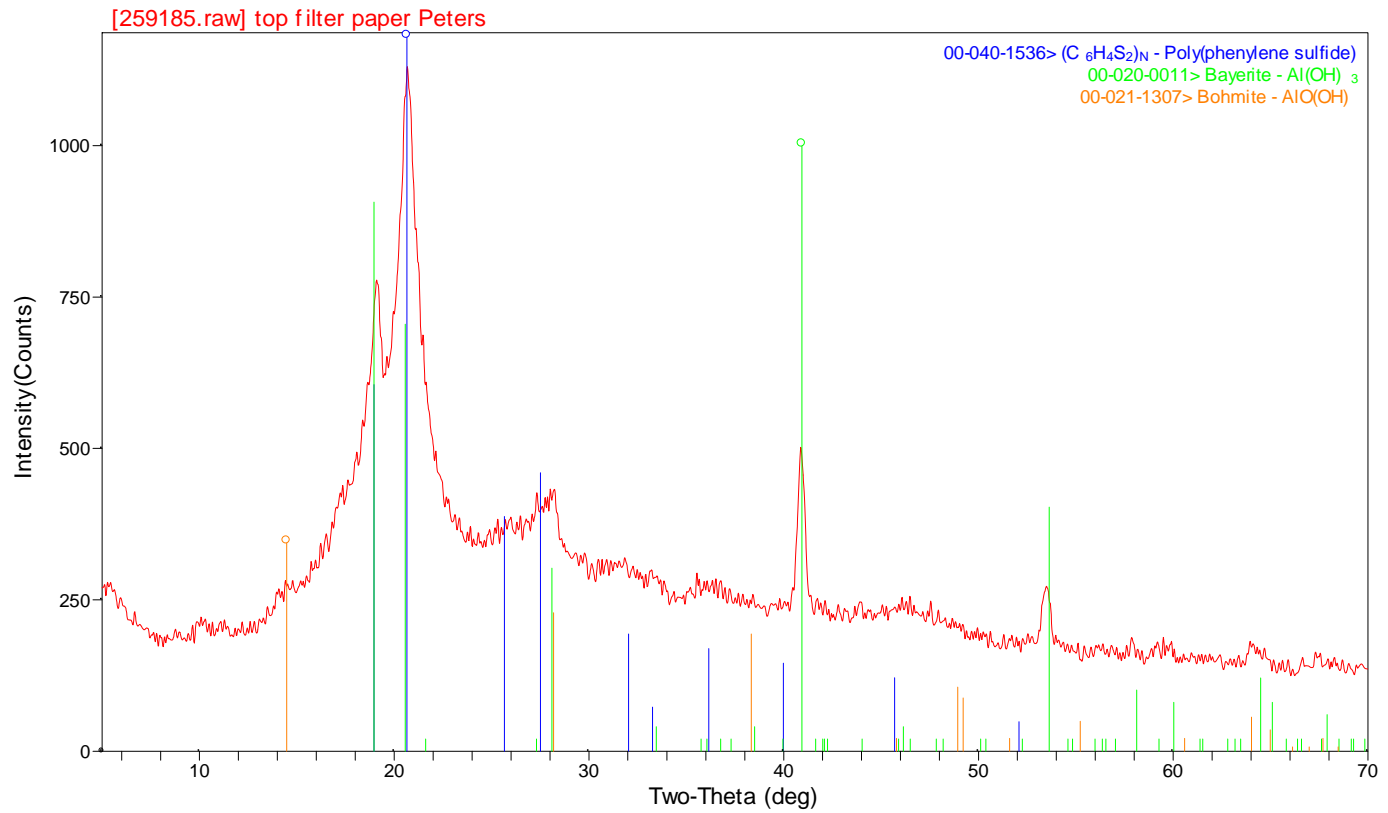

Figure 5. XRD Spectra \# 2 for Coalescer Beta

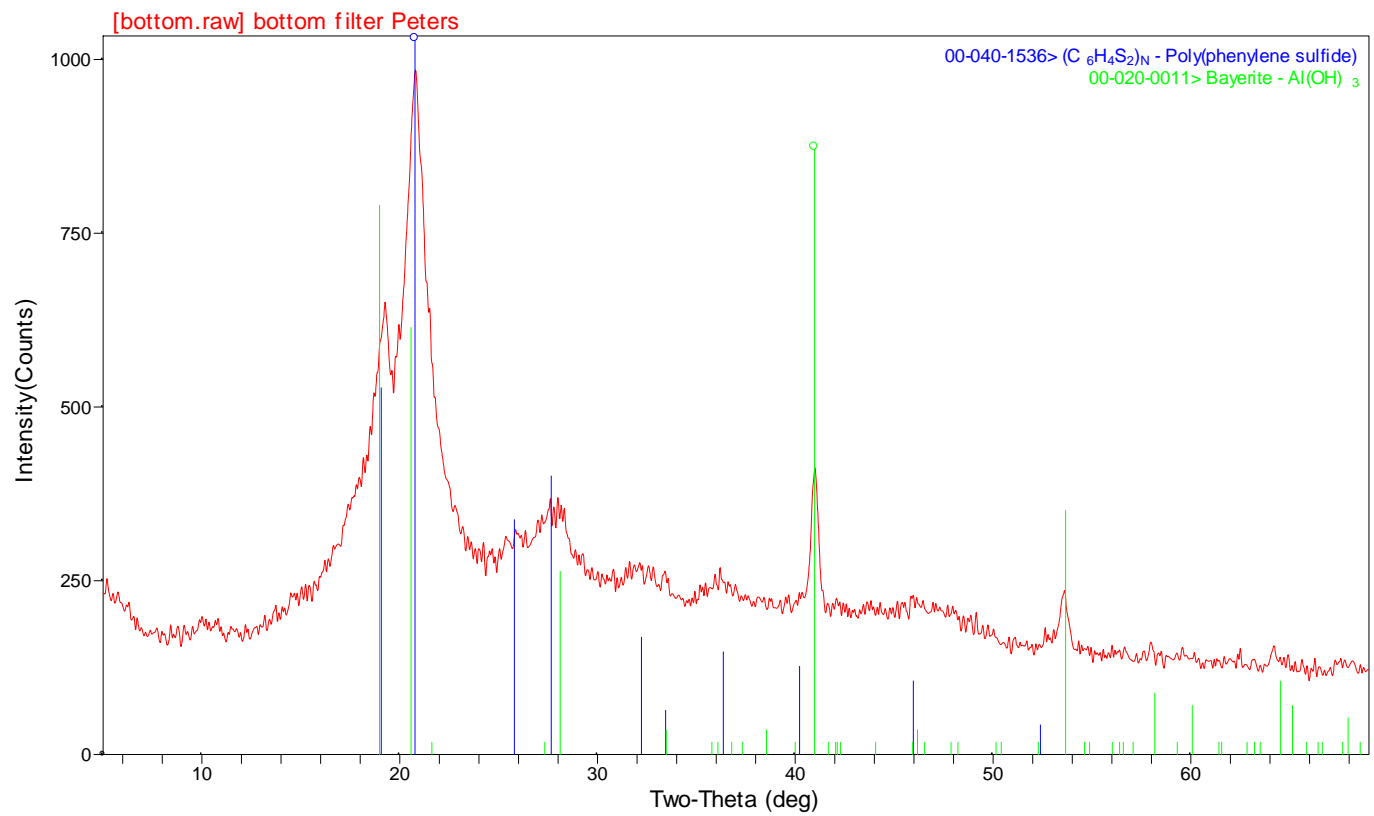


All samples show aluminum hydroxide solids (bayerite or boehmite) as the major component (not counting the polyphenylene sulfide, which is the coalescer material). Coalescer Alpha shows detectable amounts of aluminosilicates present. The lack of aluminosilicate solids in the Coalescer Beta samples is most likely an indication that the increased free hydroxide in Macrobatch 2 (i.e., 2.70 M compared to $0.61 \mathrm{M}$ in Macrobatch 1) is suppressing the formation of aluminosilicate solids, as intended. However, the greater quantity of leached aluminum in coalescer Beta (see Table 1) may indicate a higher degree of amorphous aluminum oxyhydroxide materials present.

Gibbsite is a third common type of aluminum compound, and can convert to and from bayerite and boehmite. Ongoing studies of the Decontaminated Salt Solution (DSS) coalescer shows the presence of gibbsite - something that is not found in the SE coalescer samples. This lack of gibbsite in the SE coalescer may give us insight into the formation mechanism. A paper by Navrotsky et al., ${ }^{3}$ determined that similar aluminum compounds would form different polymorphs depending on the surface area of the material. If this is the case in the coalescers, the lack of gibbsite may be an indicator of a nucleation mechanism or particle size for the precipitated aluminum oxyhydroxide materials (bayerite, boehmite, gibbsite). However, further quantitative and qualitative studies will be necessary to confirm this hypothesis.

3.2 Leaching Studies SRNL also performed a leaching study for the coalescers. From fresh samples of both coalescers, we cut $\sim 1$ square inch of the inner layer material. Each of the samples was soaked in $100 \mathrm{~mL}$ of various solutions - either $0.85 \mathrm{M} \mathrm{HNO}_{3}, 3 \mathrm{M} \mathrm{HNO}_{3}$, or 5 $\mathrm{M} \mathrm{NaOH}$. Filtered samples were pulled from each bottle at 1 hour and at 1, 14 and 28 days after the start of the dissolution. Table 1 lists the results for selected relevant analytes from Coalescer Alpha. Table 2 lists the results for selected relevant analytes from Coalescer Beta.

A number of trends appear in the leaching data. In comparing coalescer Alpha and Beta, we see that Alpha has more sodium, while Beta has more aluminum, chromium and titanium. Iron and silicon appear to be approximately equal in Alpha and Beta.

For Coalescer Apha, the sodium levels do not increase over time, which indicates the sodium is most likely from dissolved sodium salts in the SE stream, and not from entrapped solids on the coalescer. A review of nitric acid assay documents indicates that that should not be source for sodium, either. 
Table 1. Chemical Results of Coalescer Alpha Leaching

\begin{tabular}{|c|c|c|c|c|c|c|c|}
\hline Leach Time & LIMS \# & $\mathrm{Al}(\mathrm{mg} / \mathrm{L})$ & $\mathrm{Fe}(\mathrm{mg} / \mathrm{L})$ & $\mathrm{Cr}(\mathrm{mg} / \mathrm{L})$ & $\mathrm{Na}(\mathrm{mg} / \mathrm{L})$ & $\mathrm{Si}(\mathrm{mg} / \mathrm{L})$ & Ti (mg/L) \\
\hline \multicolumn{8}{|c|}{$0.85 \mathrm{M} \mathrm{HNO}_{3}$} \\
\hline 1 hour & 300258086 & 3.47 & 2.99 & 0.131 & 11.7 & $<0.593$ & 0.167 \\
\hline 1 day & 300258088 & 2.39 & 1.44 & 0.0760 & 11.2 & $<0.593$ & 0.115 \\
\hline 14 days & 300258284 & 4.85 & 4.63 & 0.168 & 11.7 & 0.941 & 0.180 \\
\hline 28 days & 300258286 & 5.08 & 4.95 & 0.178 & 11.2 & 1.45 & 0.188 \\
\hline \multicolumn{8}{|c|}{$3 \mathrm{M} \mathrm{HNO}_{3}$} \\
\hline 1 hour & 300258090 & 6.13 & 1.86 & 0.103 & 8.92 & $<0.593$ & 0.115 \\
\hline 1 day & 300258092 & 7.54 & 3.43 & 0.153 & 9.95 & 0.919 & 0.128 \\
\hline 14 days & 300258288 & 7.95 & 4.76 & 0.188 & 9.13 & 1.61 & 0.134 \\
\hline 28 days & 300258290 & 8.36 & 5.29 & 0.202 & 8.95 & 1.95 & 0.142 \\
\hline \multicolumn{8}{|c|}{$5 \mathrm{M} \mathrm{NaOH}$} \\
\hline 1 hour & 300258094 & $<4.17$ & $<4.26$ & $<0.606$ & $1.11 \mathrm{E}+05$ & $<5.93$ & $<0.133$ \\
\hline 1 day & 300258096 & $<4.17$ & $<4.26$ & $<0.606$ & $1.08 \mathrm{E}+05$ & $<5.93$ & $<0.133$ \\
\hline 14 days & 300258292 & $<10.0$ & $<2.44$ & $<0.606$ & $1.04 \mathrm{E}+05$ & $<3.01$ & $<0.208$ \\
\hline 28 days & 300258294 & $<8.0$ & 2.99 & $<0.606$ & $1.10 \mathrm{E}+05$ & $<5.93$ & $<0.133$ \\
\hline \multicolumn{8}{|c|}{ Source Material - Macrobatch $1^{4}$} \\
\hline NA & NA & $9.16 \mathrm{E}+03$ & $8.67 \mathrm{E}+00$ & $8.93 \mathrm{E}+01$ & $1.21 \mathrm{E}+05$ & $<8.64 \mathrm{E}+01$ & $<6.25 \mathrm{E}+00$ \\
\hline
\end{tabular}

$\mathrm{NA}=$ No Measurement Taken Analytical uncertainty is $10 \%$.

Table 2. Chemical Results of Coalescer Beta Leaching

\begin{tabular}{|c|c|c|c|c|c|c|c|}
\hline Leach Time & LIMS \# & $\mathrm{Al}(\mathrm{mg} / \mathrm{L})$ & $\mathrm{Fe}(\mathrm{mg} / \mathrm{L})$ & $\mathrm{Cr}(\mathrm{mg} / \mathrm{L})$ & $\mathrm{Na}(\mathrm{mg} / \mathrm{L})$ & $\mathrm{Si}(\mathrm{mg} / \mathrm{L})$ & $\mathrm{Ti}(\mathrm{mg} / \mathrm{L})$ \\
\hline \multicolumn{8}{|c|}{$0.85 \mathrm{M} \mathrm{HNO}_{3}$} \\
\hline 1 hour & 300260221 & 0.751 & 0.640 & $<0.0606$ & $<3.00$ & $<0.593$ & 0.889 \\
\hline 1 day & 300260223 & 4.15 & 2.45 & 0.279 & $<3.00$ & $<0.593$ & 7.57 \\
\hline 14 days & 300260233 & 19.0 & 3.22 & 0.393 & $<3.00$ & $<0.593$ & 10.5 \\
\hline 28 days & 300260378 & 33.0 & 3.53 & 0.421 & 1.90 & $<0.301$ & 11.1 \\
\hline \multicolumn{8}{|c|}{$3 \mathrm{M} \mathrm{HNO}_{3}$} \\
\hline 1 hour & 300260225 & 2.50 & 2.41 & 0.262 & $<3.00$ & $<0.593$ & 6.93 \\
\hline 1 day & 300260227 & 25.2 & 4.17 & 0.525 & $<3.00$ & $<0.593$ & 15.1 \\
\hline 14 days & 300260235 & 64.4 & 4.75 & 0.644 & $<3.00$ & $<0.593$ & 15.5 \\
\hline 28 days & 300260379 & 72.1 & 5.22 & 0.706 & 2.45 & 0.725 & 16.0 \\
\hline \multicolumn{8}{|c|}{$5 \mathrm{M} \mathrm{NaOH}$} \\
\hline 1 hour & 300260229 & $<5.23$ & 1.41 & $<0.606$ & $1.17 \mathrm{E}+05$ & $<3.01$ & $<0.605$ \\
\hline 1 day & 300260231 & 40.5 & 2.05 & $<0.606$ & $1.15 \mathrm{E}+05$ & $<3.01$ & 1.48 \\
\hline 14 days & 300260237 & 53.5 & 3.03 & $<0.606$ & $1.29 \mathrm{E}+05$ & $<3.01$ & 2.25 \\
\hline 28 days & 300260380 & 47.3 & 2.26 & $<0.606$ & $1.14 \mathrm{E}+05$ & $<3.01$ & 2.18 \\
\hline \multicolumn{8}{|c|}{ Source Material - Macrobatch $2^{5}$} \\
\hline NA & NA & $7.07 \mathrm{E}+03$ & $1.90 \mathrm{E}+00$ & $5.93 \mathrm{E}+01$ & $1.28 \mathrm{E}+05$ & $4.82 \mathrm{E}+01$ & $<0.199$ \\
\hline
\end{tabular}

$\mathrm{NA}=$ No Measurement Taken Analytical uncertainty is $10 \%$. 
The iron levels in the leachates show an overall increase over time for each type of leaching solution (other than the $5 \mathrm{M} \mathrm{NaOH}$ in the Coalescer Beta leachate, which gives only one real value). The source of the iron is a matter of conjecture, but is likely to be from entrained stainless steel particles fines in the ARP or MCU system. ${ }^{6}$ As corroboration, the leaching data shows the presence of increasing amounts of chromium in the $0.85 \mathrm{M}$ and $3 \mathrm{M}$ acid leaches in both coalescer samples. As stainless steels contain chromium, leaching of iron into solution may also be accompanied by leaching of chromium into solution. The high detection limits in the caustic leaches prevent any interpretation of the chromium data in those samples. We do not see any evidence of stainless steels in the XRD analyses. However, if the steel particles were very fine and relatively low mass concentration, they probably could be buried deeper in the coalescer material and not visible to the XRD method.

For the aluminum data, all the samples in both coalescers show an increase over time, with the exception of the $5 \mathrm{M} \mathrm{NaOH}$ leaching in Coalescer Beta, which is due to the high detection limits in those samples. This is a clear indication that there are aluminum-containing solids on the coalescer. The leachates from Coalescer Beta contain nearly $\sim 10 \times$ the Al concentrations as found in Coalescer Alpha solutions suggesting increased relative solids loading. Historically there are two types of aluminum containing solids that can be found on the coalescers, aluminosilicates (of many different varieties), and aluminum oxyhydroxides (i.e., bayerite, boehmite, and gibbsite). The XRD results for all of the coalescer samples corroborate the presence of bayerite and gibbsite.

The leachate silicon data shows no trend for Coalescer Beta, while Coalescer Alpha shows an increase in silicon in solution for the acid leaches. Again, we can discern no trend in the caustic leach due to the high detection limit in those samples. Coalescer Alpha leach solutions also appear to contain a higher final concentration of silicon. The presence of the silicon in-growth corroborates the XRD aluminosilicate result for Coalescer Alpha.

The leachate titanium data shows that there is a difference between Coalescers Alpha and Beta. In Coalescer Alpha, all the data shows no substantial change over time. This suggests one of several possibilities.

The first possibility is that the sample contained soluble titanium in a free liquid that was sorbed onto the surface of the sample, which immediately dissipated into the leaching solution. Considering the effective dilution that any soluble titanium would undergo in the second case, we consider this less likely, as the undiluted liquid would have to be low volume and thus very concentrated in titanium. For example, if we had $1 \mathrm{~mL}$ of this hypothetical free liquid, the soluble titanium would have to be $\sim 100 \mathrm{x}$ what was detected, or about $16 \mathrm{mg} / \mathrm{L}$. This level of soluble titanium is far higher than we have previously measured in scrub or strip acid solutions from MCU. 
A second, and most likely, potential source is enhanced solubility or leaching of Ti from MST at the higher free hydroxide concentrations in Macrobatch 2. Studies are currently in progress to examine this potential cause. For Coalescer Beta, there is a consistent in-growth of titanium in solution in all the leaching solutions indicating the presence of Ti-containing solids; with the lower levels in the caustic leaching probably indicating that the caustic is not as effective at dissolution. The obvious candidate for the source of the titanium is from the monosodium titanate (MST) at ARP. The MST solids would be dissolving at ARP due to exposure to high levels of free hydroxide, and re-precipitating later on in the MCU system, and caught on the pre-filter and coalescer. SRNL will prepare a full report on the MST leaching studies when the work in complete.

Previous analyses of DSSHT samples shows the presence of titanium in solution, at higher levels than the source material. ${ }^{5}$ Averaged across all DSSHT samples, there is $4.76( \pm 1.77)$ $\mathrm{mg} / \mathrm{L}$ of titanium in the DSSHT. The coalescer material $\left(\right.$ Ryton $\left.^{\circledR}\right)$ is declared ${ }^{7}$ to contain levels of titanium exceeding 1 ppm, but whether or not this would leach from the Ryton ${ }^{\circledR}$ under the MCU conditions is unknown. We do not consider high titanium leaching to be likely since we have not observed these Ti concentrations in prior MCU samples, but cannot disprove it at this time. SRNL recommends performing a leach test on an unused sample of Ryton ${ }^{\circledR}$ to determine the titanium leaching.

While there is no indication of titanium compounds from the XRD data (Figures 1 and 2), this is due to the difficulty in seeing amorphous MST-type Ti-oxides in this analytical method.

If we assume that after one month all of the material has leached from the coalescer samples (using the $3 \mathrm{M}$ nitric acid as the leach solution), then the amount of aluminum leached represents $\sim 95 \mathrm{mg}$ of $\mathrm{Al}(\mathrm{OH})_{3}$ across the entire 10" length of Coalescer Alpha and $\sim 818 \mathrm{mg}$ of $\mathrm{Al}(\mathrm{OH})_{3}$ across the entire 10" length of Coalescer Beta. In previous work, ${ }^{8}$ we estimated that an unmodified DSS coalescer (which has a 20 micron porosity, compared to the 10 porosity of the SE coalescer) to have a dirt capacity of $\sim 20$ grams. Presumably the dirt capacity of a SE coalescer (which is $1 / 4$ the length of the DSS coalescer, and half the porosity) would have a smaller dirt capacity. It may be that the acid flushes used to clean the SE coalescer before removal removed some fraction of the trapped particulates.

The question arises about the method by which these solids are being entrained into the SE stream. The only apparent avenue is one of carryover - when the feed material from ARP enters the extraction contactors, the counter-current solvent can entrain a small amount of aqueous material or fine solids into the organic phase. This material is then carried to the scrub contactors, where the solvent is contacted with $0.05 \mathrm{M}$ nitric acid. The aqueous phase is separated from the organic, and so the scrub can carry off some of the material entrained in the organic phase. Material that is retained in the organic phase can then be carried to the strip contactors, where it is contacted with $0.001 \mathrm{M}$ nitric acid. Material lost to the strip acid 
is evidenced by analysis of samples from the strip effluent hold tank (SEHT). Finally, the SE coalescer can retain aqueous material, and this material is evidenced in the leaching tests.

Considering the appreciable variance in the sodium levels from the Coalescer Alpha and Coalescer Beta leachates, it is more insightful to look at the sodium to aluminum ratios for the acid leachates. In Coalescer Alpha, the sodium and aluminum are comparable in concentration, while in Coalescer Beta, there is much more aluminum than sodium. As the sodium to aluminum ratio in the source feeds for both coalescers are nearly same, it then stands to reason that the great disparity in the sodium to aluminum ratio in the leachates means that the leachate concentrations are from solids that are contained on the coalescer surfaces, and dissolved into the strip acid. This in turn means that in the extraction contactors, solids are being carried over into the organic solvent - or caustic solution is being entrained into the solvent. Then, upon contact with the scrub acid, solids remain or are precipitating but still remain to some degree in the organic solvent. Finally, upon contact with the strip acid, the solids in the solvent are carried into the SE coalescer are trapped there - to be dissolved during out leaching tests.

\subsection{Free Liquid Analyses Before Coalescers Alpha and Beta were removed from MCU,} they underwent an acid flush to reduce the dose. The coalescers were then removed and sent to SRNL. As received, the SE coalescers contained a small quantity of entrapped ("free") liquid. Samples of these liquids were removed from the cells and analyzed by ICEPS, $\mathrm{pH}$ and SVOA. Table 4 shows the results from these analyses. These results must be taken in the context of the coalescers having sat in plastic bags for some number of days before being removed and analyzed. During that time, both the aqueous and organic liquids can evaporate. It is impossible to estimate the degree of evaporation.

The results of the free liquid samples are consistent with strip acid having dissolved small quantities of solids. None of the elemental analytes are a strong indicator of large amounts of solids being present in the SE coalescer. 
Table 4. ICPES and SVOA Results from Analyses of the Free Liquids

\begin{tabular}{|c|c|c|}
\hline Analyte & \multicolumn{2}{|c|}{ Result (mg/L) } \\
\hline $\begin{array}{c}\text { Coalescer Alpha } \\
\text { Coalescer Free Liquid } \\
\text { (LIMS 300257506) }\end{array}$ & $\begin{array}{c}\text { Coalescer Beta } \\
\text { Coalescer Free Liquid } \\
\text { (LIMS 300259128) }\end{array}$ \\
\hline $\mathrm{Al}$ & 0.857 & 0.341 \\
\hline $\mathrm{Ca}$ & 0.527 & 10.4 \\
\hline $\mathrm{Cr}$ & 0.0633 & $<0.0214$ \\
\hline $\mathrm{Fe}$ & 0.284 & 0.731 \\
\hline $\mathrm{Mg}$ & 0.131 & 0.395 \\
\hline $\mathrm{Mn}$ & 0.339 & 0.0750 \\
\hline $\mathrm{Na}$ & 113 & 22.6 \\
\hline $\mathrm{Ni}$ & $<0.160$ & $<0.0914$ \\
\hline $\mathrm{P}$ & 6.87 & 0.813 \\
\hline $\mathrm{S}$ & 5.45 & 7.59 \\
\hline $\mathrm{Si}$ & 0.570 & 2.06 \\
\hline $\mathrm{Ti}$ & 0.0421 & $<0.00415$ \\
\hline $\mathrm{Zn}$ & 0.0432 & 20.0 \\
\hline Isopar L & 81 & $<33$ \\
\hline Modifier & 130 & 3.5 \\
\hline $\mathrm{pH}$ & not measured & $<50$ \\
\hline
\end{tabular}

The analytical uncertainty associated with the ICPES is $10 \%$ and $20 \%$ for SVOA.

The liquid from Coalescer Alpha contained both Isopar $\mathrm{L}^{\mathrm{TM}}$ and Modifier. The low Isopar $\mathrm{L}^{\mathrm{TM}}$ to Modifier concentration ratio $(0.61)$ is probably indicative of the evaporation of Isopar $\mathrm{L}^{\mathrm{TM}}$ or of a possible affinity of the coalescer media to bind Modifier. As a comparison, the Isopar $\mathrm{L}^{\mathrm{TM}}$ to Modifier concentration ratio is 2.32 in freshly prepared solvent. SRNL and the customer should consider developing an experiment to determine if the Modifier will preferentially cling to the Ryton ${ }^{\circledR}$ material.

We can compare the concentration ratios of aluminum and sodium in the free liquid against the source material and the leachates (Table 5) from Coalescers Alpha and Beta.

Table 5. Comparison of Selected Analytes

\begin{tabular}{|c|c|}
\hline Data Set & Al/Na ratio \\
\hline Alpha leachate & 0.934 \\
\hline Alpha free liquid & 0.00758 \\
\hline Alpha source & 0.0757 \\
\hline Beta leachate & 29.4 \\
\hline Beta free liquid & 0.0151 \\
\hline Beta source & 0.0552 \\
\hline
\end{tabular}


The data indicates that the concentration ratio of aluminum to sodium varies greatly between the leachates, the free liquids, and the source material. The $\mathrm{Al} / \mathrm{Na}$ concentration ratios for the free liquids are much closer to the source material than the leachates. This is another indication of the presence of aluminum containing solids.

3.4 Microscopy Studies Samples of Coalescers Alpha and Beta were analyzed by FTIR and examined by optical microscopy.

To establish a baseline for comparison, microscopy was done on a clean, unused piece of the coalescer (Figure 4). The fibers show some cross-linking and agglomeration, but are generally separate threads.

\section{Figure 4. Optical Microscopy of the Unused Coalescer}

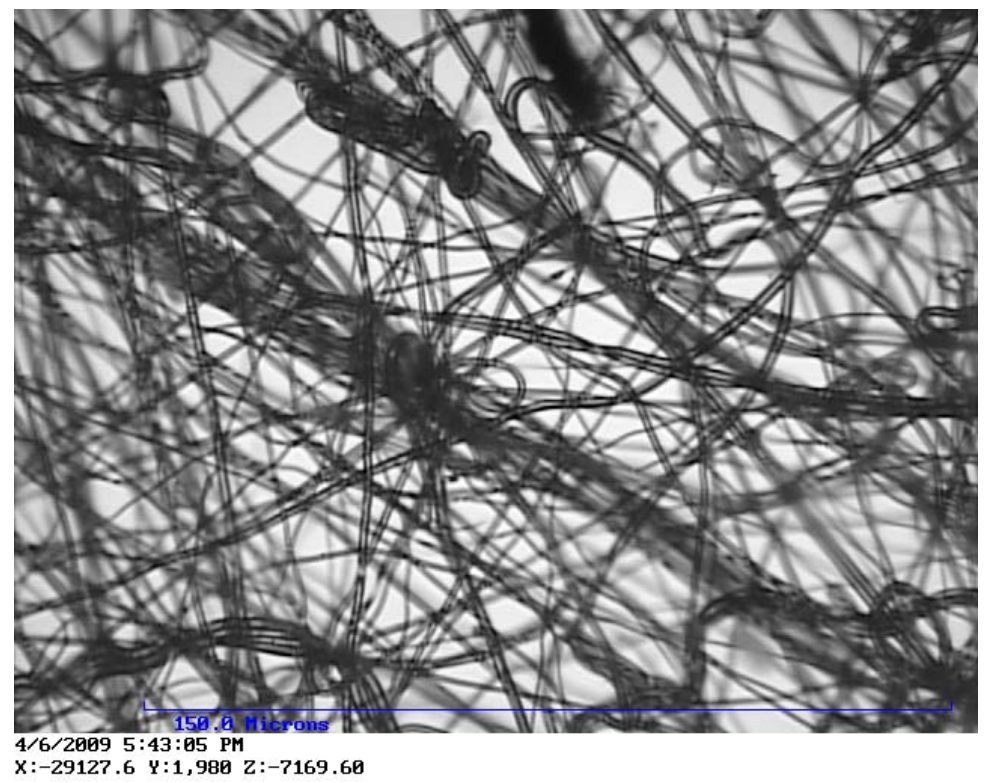

When examined, a slice of material from Coalescer Alpha (Figure 5) shows evidence of solids deposited in various parts. The material shown is taken from the internal radial surface of the media immediately adjacent to a perforation in the stainless steel support tubing. However, there appears to be a large fraction of the void space still open and available to flow. 
Figure 5. Optical Microscopy of Inner Surface of Coalescer Alpha

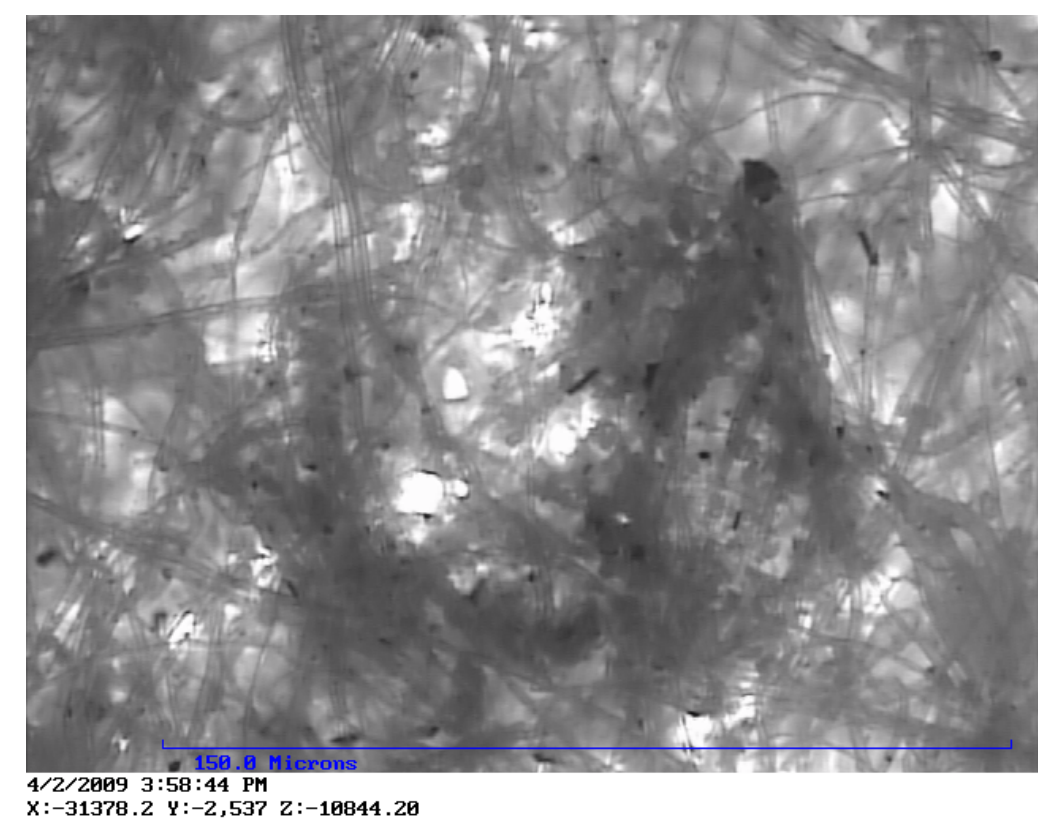

While Coalescer Alpha shows some solids, microscopy of Coalescer Beta shows evidence of more extensive solids deposition (Figure 6). Again, the material shown is taken from the internal radial surface of the media immediately adjacent to a perforation in the stainless steel support tubing.

Figure 6. Optical Microscopy of Inner Surface of Coalescer Beta

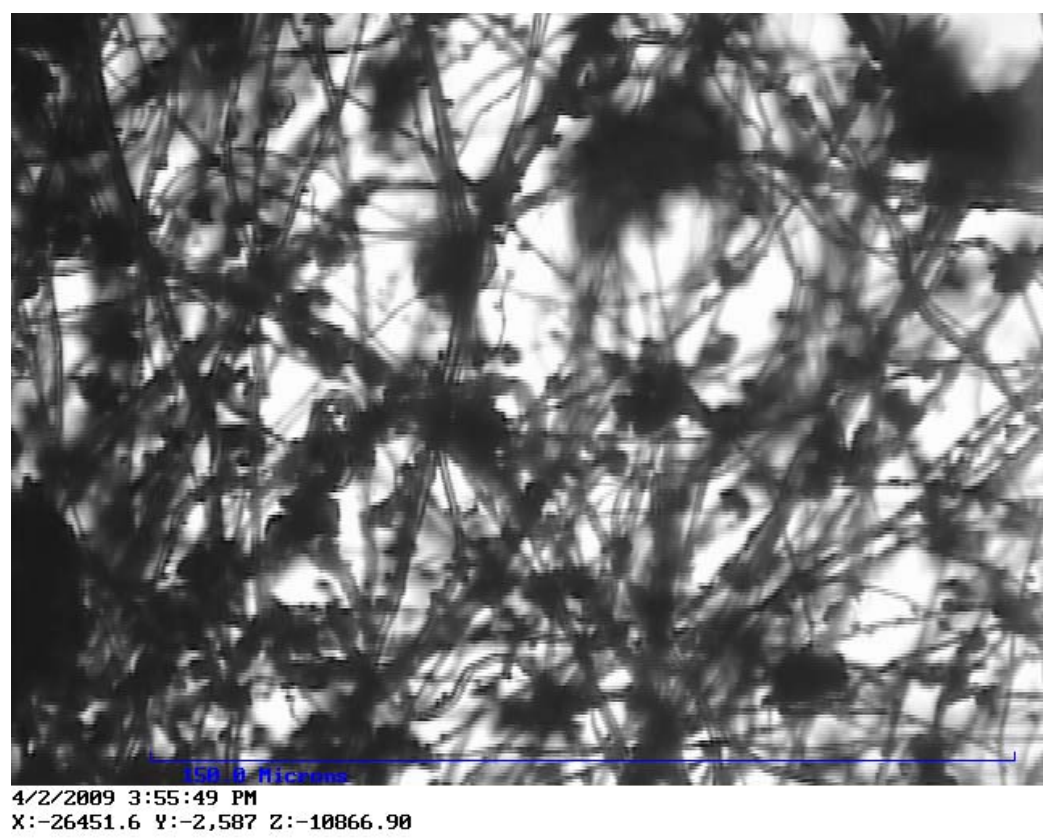


Not only are there extensive deposits on the surface of the coalescer media, the solids show greater bridging across the fibers. Figure 7 shows the optical microscopy at a radial depth of $\sim 300$ microns into the fibers (from the internal diameter of the coalescer).

\section{Figure 7. Optical Microscopy of 300 micron Radial Depth (from Inner Surface) of Coalescer Beta}

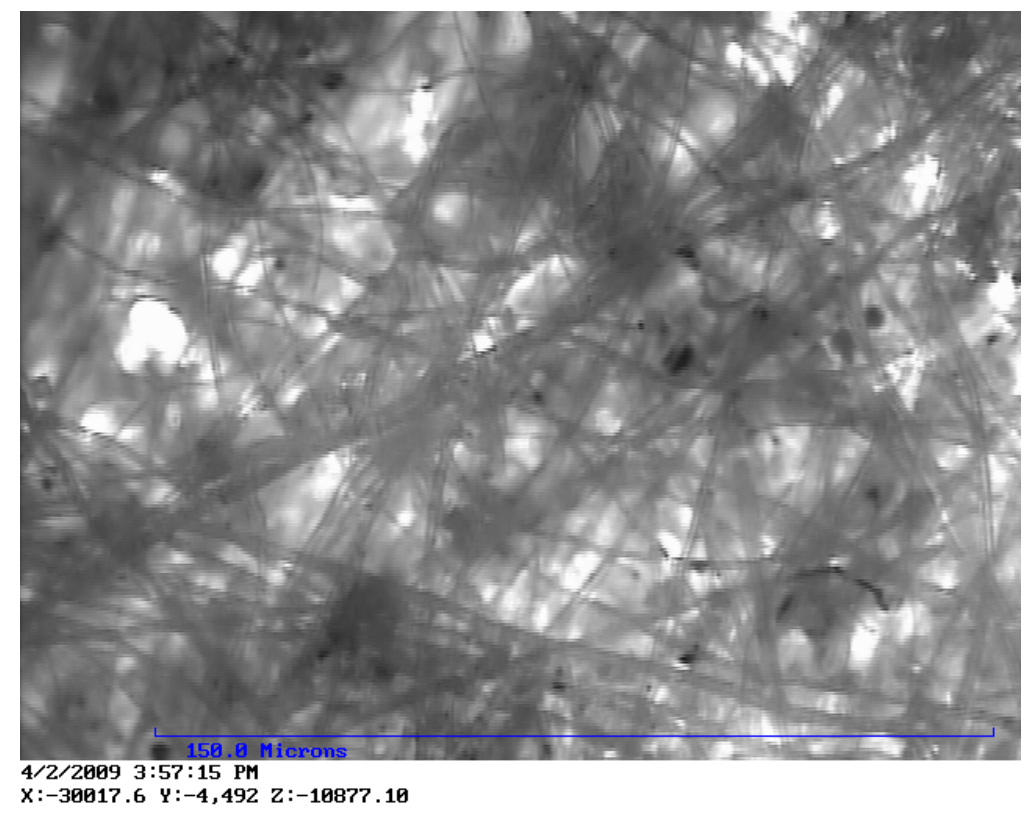

It appears from higher magnification of the occluded fibers that the fibers can serve as nucleation spots (Figure 8-9). Near the flow inlet (Figure 8), the dissolved chemicals apparently are precipitating on the deposited solids, growing crystals "heterogeneously" from the solution. Deeper into the coalescer media and away from the flow inlet (Figure 9), we observe significantly fewer solids. Note that the deposited solids are comparable to or smaller in diameter than the fiber. This suggests that these inorganic solids are nucleating on the surface. If the trapping mechanisms were simply wetting and physical trapping, one would expect to see a higher population of solids interior to the media. Also, the inorganic salts are bridging the fibers near the inlet regions for flow - i.e., where hydrodynamic forces to carry them away are highest - the precipitation kinetics seem appreciably rapid. 
Figure 8. Optical Microscopy of Solids Bridging Fibers of Coalescer Beta. This image is directly from an inlet flow area of the coalescer.

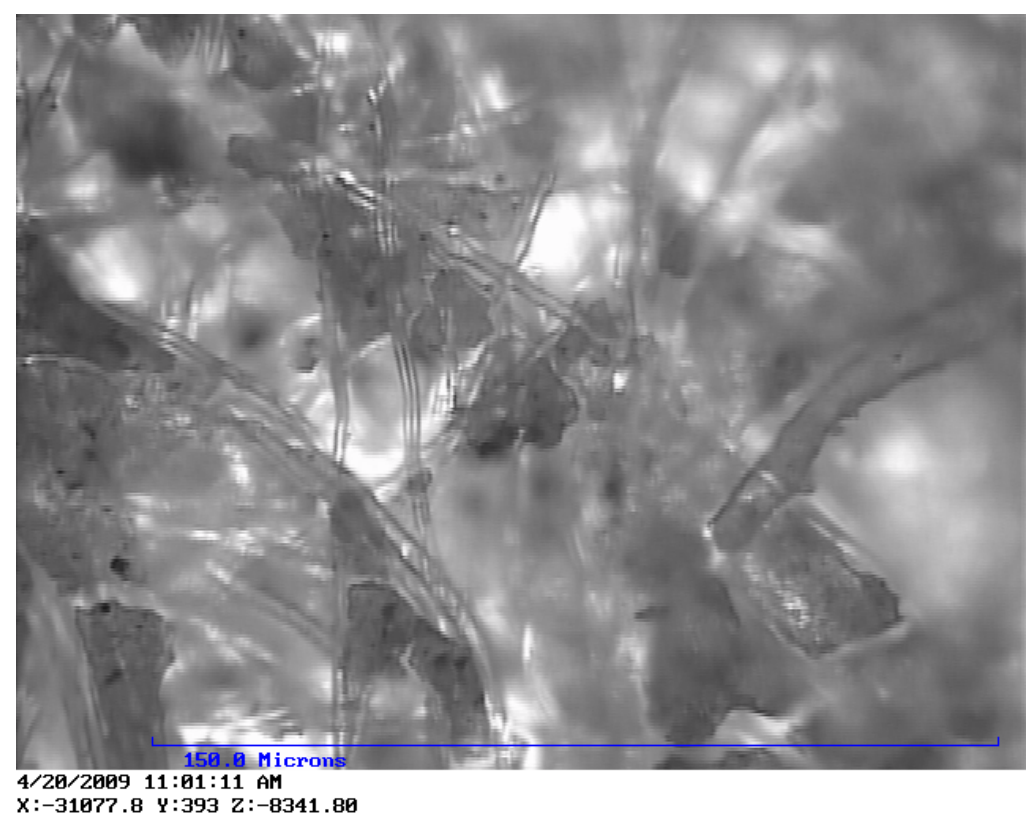

Figure 9. Optical Microscopy of Solids Nucleation Sites on Coalescer Beta. This image is taken from a position distant from the inlet flow area to the coalescer.

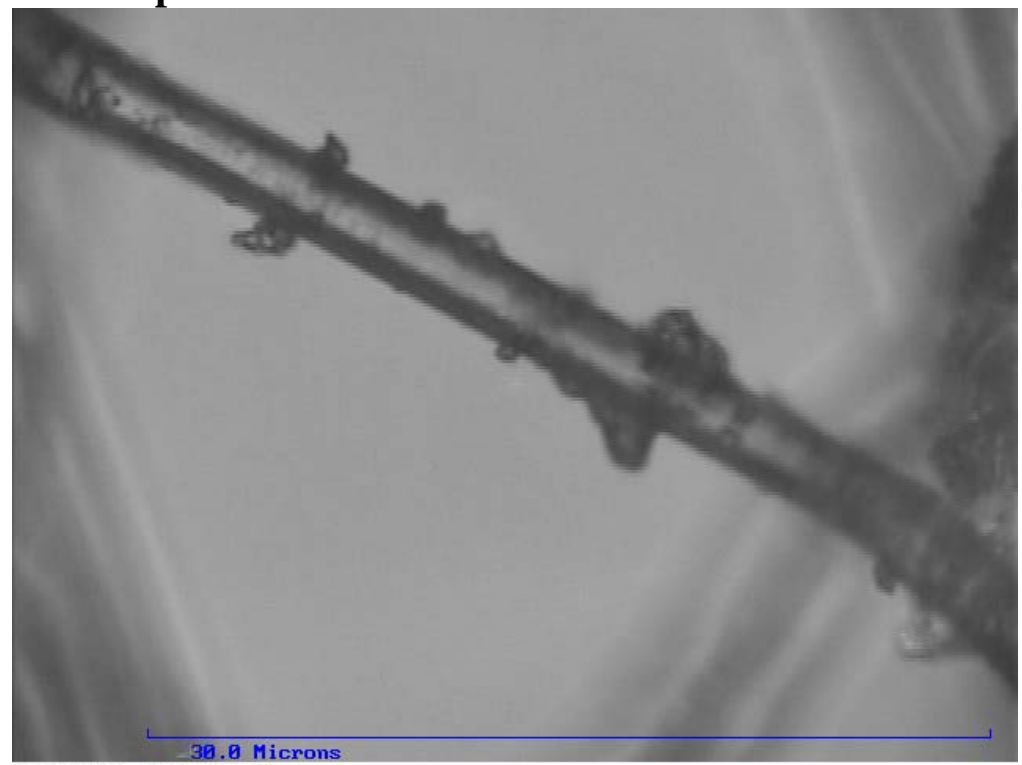


Figure 10 shows an Optical Microscopy-FTIR mapping for Coalescer B. The upper left image is an FTIR rastering of the sample surface; the upper right image is the microscopic view of the same portion of the sample. In each view, the top right quadrant shows a circular ring that denotes the position of the perforation in the adjacent stainless steel tube. Hence, the area inside the circle represents the media in the immediate flow path of the strip acid as it exits the steel tubing and percolates through the fibers. From left to right, the FTIR analyzes this visual photo (the red cross happens to be 195 micrometers from the start). The axes are $\mathrm{x}-\mathrm{y}$ coordinates.

The FTIR scan plots the wavenumbers on the $\mathrm{x}$-axis and the distance from the starting point on the red line on the y-axis. The wavenumber value is the chemical fingerprint and helps identify the chemical species on the coalescer surface at a given location.

The center, right side graph is a 3-D representation of the bayerite concentration along an $x-y$ distance axes. The center of the inlet is seen to have the highest concentration of bayerite.

Finally, the two long graphs on the bottom of the figure are the FTIR results. They both show the presence of bayerite and Ryton ${ }^{\circledR}$ (i.e., the coalescer material).

In summary, this figure shows us that bayerite can be found over the entire inner surface of the coalescer, with the highest concentration - much higher then the average - being located at the flow inlet. Recall that the inlet is where the material is over a hole in the stainless steel support tube, and so the inlet is the path of least resistance for the aqueous solution to pass through, and thus should collect more solids. This data shows relative fast deposition of solid within the entry zone of flow and lessening amounts of solids at axial positions between perforations in the steel tubing.

Using image analysis, a few of the micrographs were thresholded *and transformed into binary pictures. The binary pictures were further analyzed to determine the surface area of the picture not occupied by fibers. The fraction of the area not occupied by the fibers is believed to be the empty space available for hydrodynamic flow. We conducted empty space analysis on two snapshots of the filter media (not shown). The portion of the surface area available for liquid flow in the plugged inlet coalescer measured $32 \pm 6 \%$. A similar calculation for the interior of the coalescer ( $\sim 100$ microns away from the inlet) measured $41 \pm 4 \%$.

To estimate the pressure drop increase across the coalescer due to a $14 \%$ decrease in surface area available to flow, the Kozeny-Carman relation was used assuming a linear laminar flow through the coalescer bed.

\footnotetext{
* Threshold an image means segmenting the images into a binary image (from 256 to 2) using the histogram as a ruler. Once the image is in binary format then edge detection followed by area measurements yields the percent area available for flow (not occupied by a fiber).
} 
Figure 10. FTIR Line Map of Inlet and Adjacent Area of Coalescer Beta

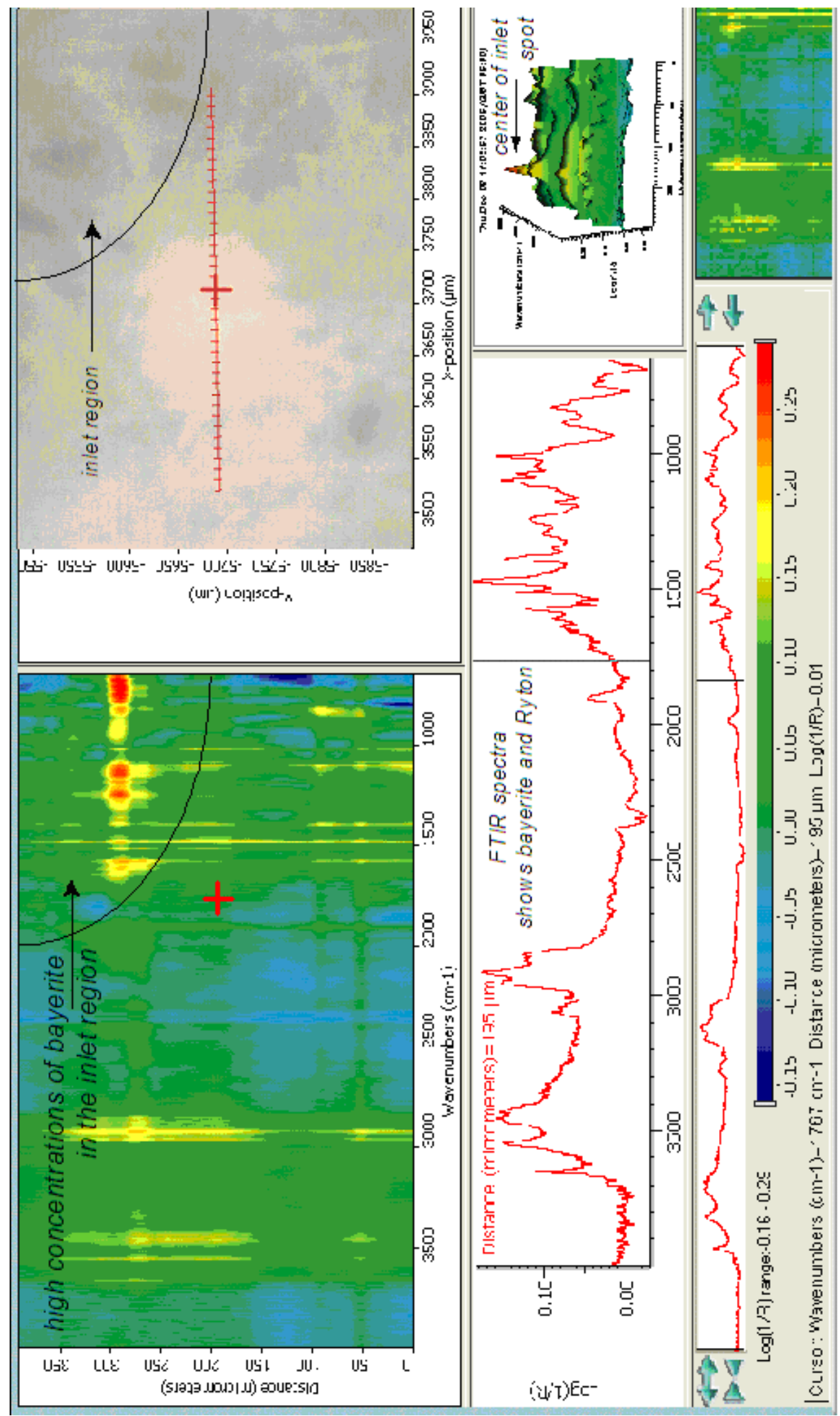


The Kozeny-Carman relation follows.

$$
\frac{\Delta P}{L}=k \times \mu \times A_{v}^{2} \times \frac{(1-\varepsilon)^{2}}{\varepsilon^{3}} \times U_{0}
$$

In equation 1 , " $\mu$ " stands for viscosity, " $\mathrm{A}_{\mathrm{v}}$ " stand for the geometrical specific area $\left(\mathrm{m}^{-1}\right)$, " $\mathrm{U}_{\mathrm{o}}$ " stands for the approaching velocity, and " $\mathrm{k}$ " is the Kozeny constant. The Kozeny constant has been found to be a function of porosity " $\varepsilon$ " as shown in Table 6 .

Taking the ratio of equation 1, we can estimate the increase in pressure drop as shown in equation 2 .

$$
\frac{\frac{\Delta P}{L_{2}}}{{\frac{\Delta P}{L_{1}}}_{1}}=\frac{\left[k \times A_{v}^{2} \times \frac{(1-\varepsilon)^{2}}{\varepsilon^{3}}\right]_{2}}{\left[k \times A_{v}^{2} \times \frac{(1-\varepsilon)^{2}}{\varepsilon^{3}}\right]_{1}}
$$

Assuming the starting porosity is approximately $90 \%$ and it decreased by $22 \%$ $(100 \% \times[1-32 \% / 41 \%])$ and the specific surface area per solid volume remain approximately constant then the increased pressure drop is listed in Table 6 for different correlations.

Table 6. Correlations for Kozeny Constant and Predicted Pressure Drop.

\begin{tabular}{|c|c|}
\hline Correlations for Kozeny constant & $\begin{array}{c}\text { Pressure per unit bed } \\
\text { length increase (PSI) }\end{array}$ \\
\hline$k=4 \times \frac{\varepsilon^{3}}{\sqrt{(1-\varepsilon)}}\left[1+56 \times(1-\varepsilon)^{3}\right]$ ref.9 & 12.03 \\
\hline$k=\frac{1.5 \times \varepsilon^{2}}{\pi \times \operatorname{Ln}\left(0.64 /(1-\varepsilon)^{2}\right)} \times \frac{1}{(1-\varepsilon)}$ ref.9 & 6.25 \\
\hline$k=5+[14 \times(\varepsilon-0.8)]^{\text {ref.. } 10}$ & 10.8 \\
\hline$k=3.5 \times \frac{\varepsilon^{3}}{\sqrt{(1-\varepsilon)}} \times\left[1+57 \times(1-\varepsilon)^{3}\right]$ ref..11 & 12.15 \\
\hline
\end{tabular}


SRNL-STI-2010-00088

\subsection{CONCLUSIONS}

Analyses of the SE coalescers provided results of fouling behavior using similar approaches as for previous analyses of DSS coalescers. ${ }^{3}$ However, the markedly reduced fouling allows greater insight into the fouling mechanism than for the DSS coalescers.

Aluminum hydroxide compounds dominate the fouling for the SE coalescer media. The results show only minor amounts of solvent remaining in the SE coalescer and no indications of large amounts of entrapped solids. Bayerite is nucleating on the Ryton ${ }^{\circledR}$ surfaces and decreasing the porosity of the coalescer as a whole.

The pressure increases calculated from the visual estimates of pore occlusion are close to the observed (Figure 2) maximum pressure drops ( 10 PSI) during steady state operations. This gives us confidence that the mechanism of pressure increases is due to solids fouling and not due to organic blinding of the flow path - or at least not due solely to organic blinding.

In theory, bayerite should be subject to easy cleaning by nitric acid, but this clearly not the case (recall that the nitric acid cleaning cycles provided little benefit). It may be that the crystalline bayerite material is more resistant to acid dissolution. 


\section{Appendix 1. Fouling of Strip Effluent Coalescer during Non-radioactive Operations}

During non-radioactive operations, on July 14, 2007, the SE coalescer showed signs of pluggage as evidenced by excessive pressure drops. ${ }^{12}$ The coalescer was removed and sent to SRNL for analysis. Optical microscopy (Figure 11) showed some fine particles in the Ryton $^{\circledR}$, but apparently not enough to cause the pressure differential s experienced at MCU. SRNL then performed FTIR and Raman spectroscopy on the solids (Figure 12).

Figure 11. Various Optical Microscopy Shots of the Plugged Non-Radiological SE Coalescer

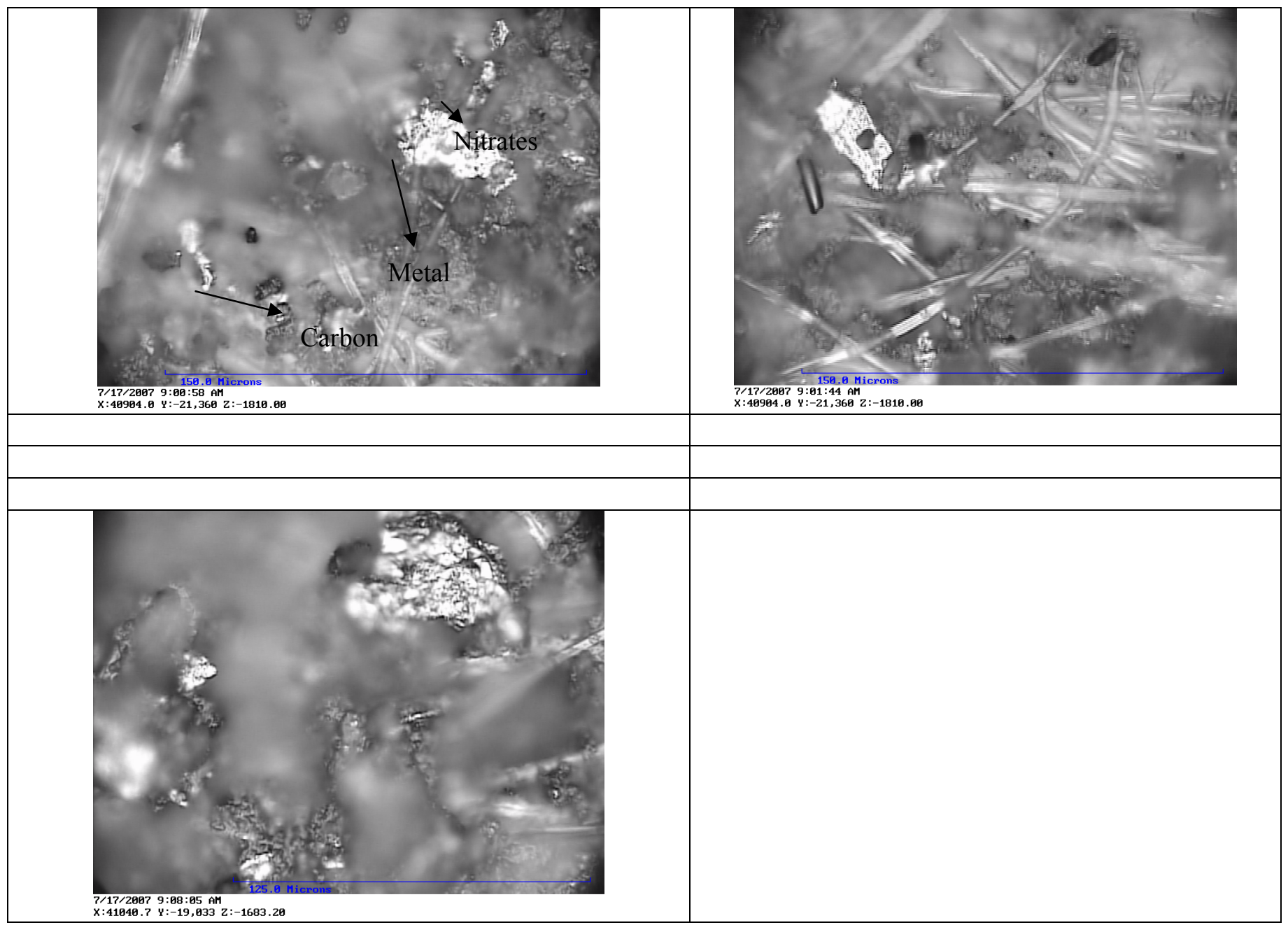


Figure 12. FTIR and Raman Spectroscopy of the Trapped Solids

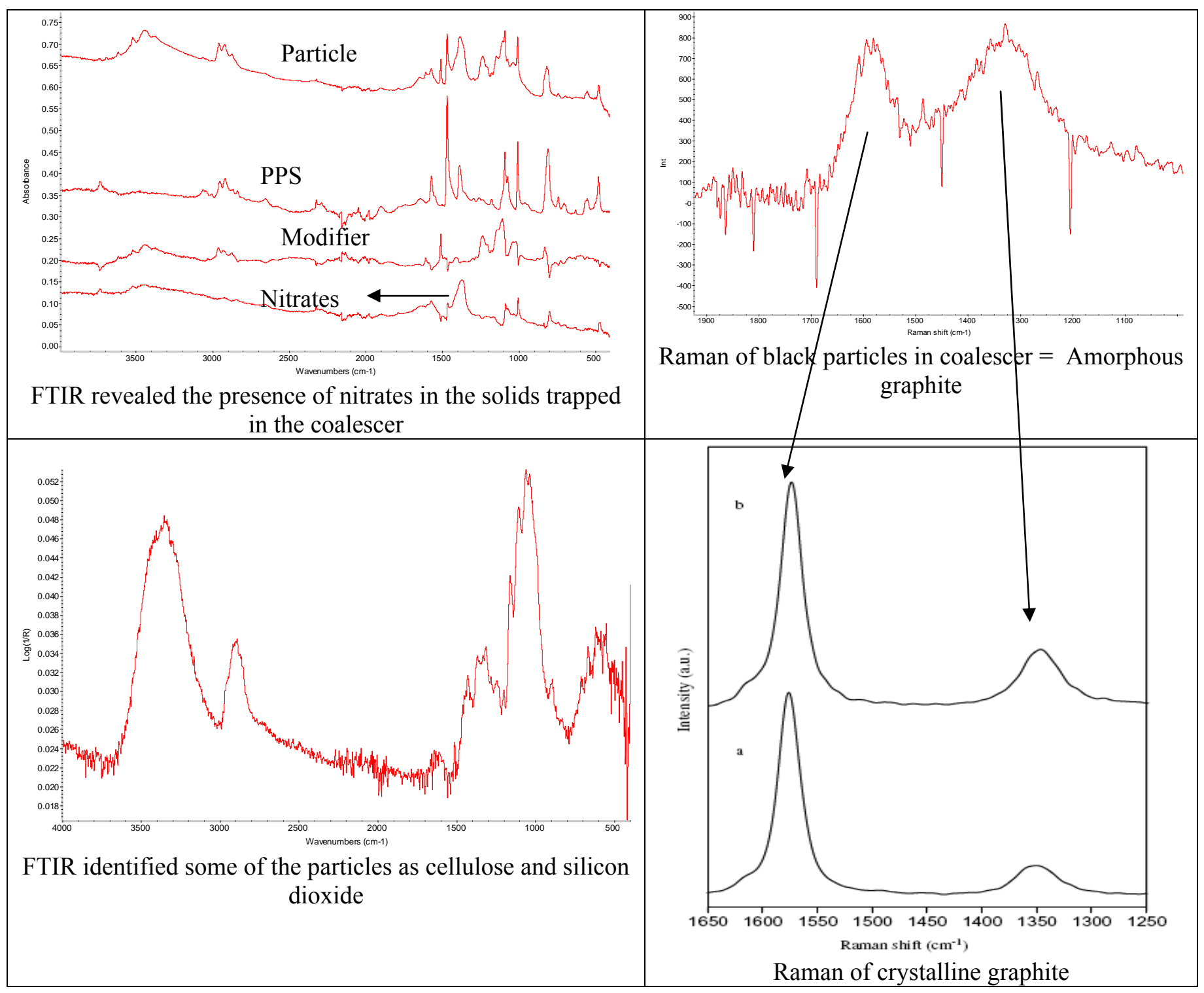

From the FTIR and Raman analyses, the particles turned out to be a variety of material graphite, stainless steel, silicon dioxide (sand), cellulose, and nitrate salts.

It turned out the solids were not responsible for the excessive pressure drops. Rather, the solvent density had drifted out of range - due to Isopar LTM evaporation - and an emulsion formed with the nitric acid. However, this data does show we have seen manufacturing debris previously in the coalescers. 
SRNL-STI-2010-00088

\subsection{References}

${ }^{1}$ T. B. Peters, F. F. Fondeur, S. D. Fink, "Diagnostic Analyses of the Decontaminated Salt Solution Coalescers from Initial Radiological Operations of the Modular Caustic-side Solvent Extraction Unit“, SRNL-STI-200800369, Rev. 0, October 12, 2008.

${ }^{2}$ R. A. Leonard and B. Moyer, "Recommendations Related to MCU Strip-Effluent Coalescer Performance," May 7, 2009.

${ }^{3}$ Navrotsky, Geochemical Transactions, 4 (1), p.34, Nov 2003 doi:10.1186/1467-4866-4-34

${ }^{4}$ C. A. Nash, T. B. Peters, S. D. Fink, "Tank 49H Salt Batch Supernate Qualification for ARP/MCU”, WSRCSTI-2008-00117, Rev. 1, August 25, 2008.

${ }^{5}$ C. A. Nash, T. B. Peters, S. D. Fink, “ISDP Salt Batch \#2 Supernate Qualification”, SRNL-STI-2008-00446, Rev. 1, January 5, 2009.

${ }^{6}$ T. B. Peters, F. F. Fondeur, S. D. Fink, "Results from Solvent Hold Tank and Other Samples during March 2010 Outage", SRNL-STI-2010-00311, January 2011.

${ }^{7} \mathrm{http}: / /$ www.cpchem.com/bl/rytonpps/en-us/Pages/EnvironmentalEndOfLife.aspx

${ }^{8}$ M. D. Fowley, M. R. Poirier, "Testing a Modified Coalescer for the Modular Caustic-Side Solvent Extraction Unit”, SRNL-STI-2009-00324, July 6, 2009.

${ }^{9}$ F. A. L. Dullien (1979), Porous Media: Fluid Transport and Pore structure, p. 166. Academic Press, New York.

${ }^{10}$ P. Xu., B. Yu., "Developing a New Form of Permeability and Kozeny-Carman Constant for Homogenous Porous Media by Means of Fractal Geometry", Advances in Water Resources 31 (2008), pg.74-81.

${ }^{11}$ W. L. Ingmason, and B. D. Andrews (1963), "High velocity water flow through fiber mats," Tappi 46, 150155

12 S. J. Brown, “Emulsion Resolution”, LWO-SPT-2007-00194, Rev.0, August 14, 2007. 


\section{Distribution:}
A. B. Barnes, 999-W
D. A. Crowley, 773-43A
S. D. Fink, 773-A
B. J. Giddings, 786-5A
C. C. Herman, 999-W
S. L. Marra, 773-A
F. M. Pennebaker, 773-42A
E. J. Freed, 704-56H
D. J. Martin, 241-152H
M. W. Geeting, 241-152H
S. P. McLeskey, 241-152H
B. A. Gifford, 704-56H

T. B. Peters, 773-42A

C. A. Nash, 773-42A

M. R. Poirier, 773-42A

F. F. Fondeur, 773-A

P. R. Jackson, 703-56A 